\title{
Direct passive hemagglutination test for rapid quantification of plasma load of the Human Immunodeficiency Virus
}

\author{
Maduike C. O. Ezeibe ${ }^{1 *}$, Augustine A. Ngene ${ }^{1}$, Ifeanyichukwu Anene ${ }^{2}$, Bridget Amechi ${ }^{2}$, \\ Peter Olowoniyi ${ }^{2}$, James I. Eze ${ }^{1}$, Paul C. Animoke ${ }^{1}$ \\ ${ }^{1}$ Department of Veterinary Medicine, University of Nigeria, Nsukka, Nigeria; *Corresponding Author: maduikeezeibe@yahoo.com \\ ${ }^{2}$ Federal Medical Centre, Umuahia, Nigeria
}

Received 5 June 2013; revised 6 July 2013; accepted 31 July 2013

Copyright (C) 2013 Maduike C. O. Ezeibe et al. This is an open access article distributed under the Creative Commons Attribution License, which permits unrestricted use, distribution, and reproduction in any medium, provided the original work is properly cited.

\begin{abstract}
An inexpensive and rapid test for determining titers of Human Immunodeficiency Virus (HIV) in plasmas was developed. Washed sheep red blood cells were applied onto HIV positive plasmas, in V-bottomed microtiter plates, to complement the HIV antigens and antibodies present in plasmas. The setup was incubated for $\mathbf{3 0} \mathrm{min}$ utes at $37^{\circ} \mathrm{C}$. Reciprocal of the highest dilution of each plasma which gave passive agglutination of the RBCs was read as its HIV titer. Mean HIV load of five samples, was $\geq 4096.00 \pm 0.00$ after one day of storage at $4^{\circ} \mathrm{C}$ but it reduced to $256.00 \pm 70.10,28.80 \pm 3.20,7.20 \pm 0.80$ and 1.60 \pm 0.98 on days $2,3,4$ and 7 , respectively. HIV antibodies were still detectable, by ELISA, in plasma dilutions that were tested negative with the new test. It was concluded that when HIV antibodies have been confirmed, or added to plasmas, passive hemagglutination test can be applied to assess their viral loads.
\end{abstract}

Keywords: HIV; Antibodies; Antigens; Plasma; Sheep Red Blood Cells

\section{INTRODUCTION}

The HIV/AIDS pandemic is a very big health challenge in many countries, especially in Africa. At the end of 2006, an estimated 39.5 million people in the world were living with HIV, with Sub-Saharan Africa having the highest burden of the pandemic. The infection rate is increasing every year. An estimated 4.3 million new cases were reported in 2006 . More than $95 \%$ of these new infections were from poor countries of Asia, South Amer- ica and Africa [1]. There are therefore needs to develop simpler and more rapid methods of diagnosis for the infection and to research for simpler methods of assessing progression of the infection, so that researchers in the developing countries which are more at risk can join the effort to look for a cure.

The Human Immunodeficiency Virus (HIV) which causes Acquired Immune Deficiency Syndrome (AIDS) is a Lentivirus which belongs to the family, Retroviridae. It is a single stranded RNA virus that has envelope [2]. Pathogenesis of HIV infection comprises of an acute (primary) phase that lasts for months, followed by a clinically latent phase that lasts for few years before the collapse of immune responses, leading to AIDS [1].

It takes three to six weeks from date of infection for anti-HIV antibodies to appear in blood of an infected individual. So, tests that detect HIV antibodies or tests that are dependent on the antibodies would give negative results during this period. However, during this primary period there is surge of viraemia and plasma load of the virus reaching peak within 2 - 3 weeks of infection. There is also corresponding loss of lymphocytes during the period, causing a drop in circulating CD4-T lymphocytes. The host then generates immune response that leads to decline in viraemia. This acute HIV disease is usually self limiting, but about 4 - 6 months post-infection, steady state of viraemia is achieved.

The plasma virus load remains stable for several years posting plasma virus load set point. The infected person remains fairly asymptomatic during this period. Although plasma virus load levels do not rise during this period, there is still multiplication of virus, leading to destruction of the CD4-T lymphocytes [3].

As plasma viral load fluctuates, so does CD4 T-lymphocyte count. So, plasma viral load and CD4 T-lymphocyte count are the two parameters often used to assess 
progression of HIV infection and to evaluate outcome of antiretroviral therapies (ART). However, CD4 T-lymphocytes counts are also influenced by other factors such as opportunistic infections, and nutritional factors. For this reason, assessment of HIV plasma virus load is the most sensitive and most reliable parameter of monitoring progression of HIV infections and for assessing effectiveness of ARTs [1], but because tests available for quantitative detection of HIV are expensive, most laboratories and hospitals in developing countries use CD4 T-lymphocyte counts to estimate HIV viraemia.

Passive hemagglutination (PHA) test, a very simple and inexpensive test has been used to detect antibodies to HIV [4]. Comparision of use of the PHA test and use of ELISA and Western blot (Immunoblot) analysis to detect antibodies of HIV gave $100 \%$ correlation [4].

PHA test is based on reaction of antibodies and their homologous antigens which results in failure of red blood cells to sediment. So it can be used to detect both the antibodies and the antigens. By using serial dilutions of viral antigens to sensitize red blood cells, before reacting them onto known homologous antibodies, we have been able to develop a Modified Passive Hemagglutination Test and successfully used it for quantitative detection of Infectious Bursa Disease Virus [5]. It was therefore thought achievable to develop a direct passive hemagglutination (DPHA) test for rapid assessment of HIV titers in plasmas, since the antigens and their homologous antibodies coexist at high concentrations in the specimen.

\section{MATERIALS AND METHODS}

Plasma samples from five patients were confirmed positive for HIV infection with solid phase ELISA technique, by placing drops of the plasma samples on HIV test papers (Alere, Determine) to observe for color change. Positive samples were stored at $4{ }^{\circ} \mathrm{C}$ to encourage changes in HIV titers of the samples.

The Direct Passive Hemagglutination test was conducted on each of the samples by adding $0.2 \%$ sheep red blood cells to dilutions of the plasma samples [4]. To each well in rows of a $\mathrm{V}$ bottomed microtiter plate, 0.005 $\mathrm{ml}$ of phosphate buffered saline (PBS) was deposited. Equal volume $(0.005 \mathrm{ml})$ of the plasma was added to the first well in a row and was serially double diluted across. Finally, $0.005 \mathrm{ml}$ of the $0.2 \%$ sheep RBC, prepared as described by Wosu [6], was added to each dilution of the plasma. A row of wells that had only PBS and the sheep $\mathrm{RBC}$ was included in the protocol as RBC control. The setup was incubated at $37^{\circ} \mathrm{C}$ for 30 minutes when RBCs in the control wells settled to discrete buttons. Highest dilution of a plasma that gave complete passive agglutination of the RBCs was read as titer of HIV in it, on the condition that the next higher dilution of the plasma tested positive to HIV antibodies by the solid phase ELISA test.

The DPHA test was done on the samples after storage at $4{ }^{\circ} \mathrm{C}$ for one day, two days, three days, four days and seven days. Mean viral titers of the five samples, for each of the five days the test lasted, were tested for statistical differences by Analysis of variance (ANOVA), to know if the test would detect changes in titer expected of enveloped viruses stored at that temperature

\section{RESULTS}

All 5 plasma samples tested after one day at $4^{\circ} \mathrm{C}$, gave DPHA positive up to the last $\left(12^{\text {th }}\right)$ well of the plate $(\geq 4096.00)$. From second day to the seventh day at $4^{\circ} \mathrm{C}$, HIV titers of the samples reduced significantly $(\mathrm{P}<0.05)$ to $256.00 \pm 70.10,28.80 \pm 3.20,7.20 \pm 0.80$ and $1.60 \pm$ 0.98 respectively. Next higher dilutions of the plasma samples tested positive for HIV antibodies upto 7 days at $4^{\circ} \mathrm{C}$. HIV titers (DPHA) of the plasma samples stored at $4^{\circ} \mathrm{C}$ were as on Table 1.

\section{DISCUSSION}

The principle of Passive hemagglutination test is that viruses adsorb to red blood cells of given animal species as the first stage of infecting the cells. Before the viruses have time to penetrate into the cells' cytoplasm, if contact with homologous antibodies is made, they also attach to the antibodies. The resultant antibody-antigen complex prevents the RBCs from settling to discrete buttons in wells of microtiter plates, giving the impression of viral hemagglutination.

PHA is usually performed by sensitizing RBCs of given animal species with a known virus, so that when the sensitized RBCs are reacted to dilutions of serum samples, if antibodies to the virus are present in the sera, passive agglutination of the RBCs would occur. So, it is able to detect presence of viral antibodies.

To apply PHA for quantitative detection of viruses, we

Table 1. Direct passive hemagglutination titers of Human Immunodeficiency Virus in plasma of infected patients.

\begin{tabular}{cccccc}
\hline Plasma & \multicolumn{5}{c}{ Days of storage at $4^{\circ} \mathrm{C}$} \\
\hline & 1 & 2 & 3 & 4 & 7 \\
1 & $\geq 4098$ & 256 & 32 & 8 & 0 \\
2 & $\geq 4098$ & 512 & 32 & 8 & 4 \\
3 & $\geq 4098$ & 256 & 32 & 8 & 4 \\
4 & $\geq 4098$ & 128 & 32 & 4 & 0 \\
5 & $\geq 4098$ & 128 & 16 & 8 & 0 \\
Mean \pm SE & $\geq 4098$ & \pm 00.00 & $256 \pm 70.1028 .80 \pm 3.207 .20 \pm 0.801 .60 \pm 0.98$ \\
\hline
\end{tabular}


sensitized the RBCs with dilutions of specimens suspected to contain the viruses of interest and the sensitized RBCs onto sera containing known antibodies to the suspected viruses [5]. This modification of the passive hemagglutination test can be used to detect viruses, from specimens that contain only the virus while the known antibodies are in sera. In the case of HIV infection, both the virus and its antibodies are found together in plasma and in other secretions and excretions of infected patients [7]. This requires another modification of the procedures for PHA test.

To modify PHA to get the DPHA test for quantitative detection of HIV in plasma, we took advantage of the fact that plasmas of infected patients already contain high concentrations of both antibodies to HIV and the virus itself [8]. So, all that was needed was to provide susceptible RBCs and environmental conditions needed for viral adsorption to take place. At $37^{\circ} \mathrm{C}$ for 30 minutes, both adsorption of HIV onto sheep RBCs and the antigen-antibody reaction needed to produce passive agglutination of the RBCs took place.

In the passive hemagglutination test used to detect antibodies and in the Modified Passive Hemagglutination test developed for virus titers [5], either the antigen or the positive serum (antibodies) is known. So, a positive reaction identifies the unknown as homologous complement of either the known antigen or the known antibody. In the case of the Direct Passive Hemagglutination test being described, detection of HIV antibodies in the plasmas before the test, confirmed that the passive agglutination of sheep RBCs resulted from reaction of HIV antibodies present in the plama with their homologous antigens (HIV). Also, since presence of both the HIV antibodies and the virus is necessary for the passive agglutination to take place, the end point for DPHA could be as a result of exhaustion of any of the antibody or the antigen. So, it was necessary to test the next higher dilution to titer of each plasma, for HIV antibodies, to ensure that the antibodies remained and that what got exhausted was the virus. Detection of HIV antibodies in dilutions of the plasmas that could not produce positive passive agglutination of the sheep RBCs means that titers got for the DPHA test were titers of the virus in the plasma samples.

None of the plasma samples tested (before and after the DPHA test) in this study was negative for HIV antibodies but it is known that in early cases of HIV infection (the window period), plasmas of infected persons can test negative for antibodies [1]. It is also possible for antibodies in a positive plasma to be diluted out, before the antigens get exhausted. When plasmas test negative for HIV antibodies, DPHA test should be run with serum produced with purified HIV subunit antigens for antibodies that are specifically against the glycoprotein (antibodies without the virus). Serial dilutions of the speci- mens (plasmas) would then be made in the serum which contains antibodies specific against HIV glycoprotein [4]. This will ensure that dilutions of the plasmas contain high concentrations of HIV antibodies that would remain fairly constant while concentration of the virus would reduce with each dilution, until it gets exhausted.

Titers of over 4096.00 got in all the plasmas after storage at $4^{\circ} \mathrm{C}$ for 24 hours' confirming the report that both virus and antibodies to HIV occur at very high concentrations in plasmas of infected individuals [1]. Reduction in titer of the same samples, after two days at $4^{\circ} \mathrm{C}$ confirms that high temperatures are unfavorable to survival of HIV. It also shows that DPHA test is sensitive to changes in plasma HIV loads.

World Health Organization [1] reported that HIV titer in plasma is the most sensitive indicator of progression of the disease and the best parameter for assessment of efficacy of antiretroviral treatments. However, in most parts of Africa, CD4 T-lymphocyte counts are used for assessing progression of HIV infection. This is because methods currently available for assessing HIV viral loads are expensive or not available in most hospitals.

Apart from being less sensitive than determination of viral loads, lymphocyte count is a difficult and slow process. Its accuracy depends on expertise of the person counting [1]. On the other hand, the Direct Passive Hemagglutination test is a very rapid test. It takes only about 45 minutes to get results. It is inexpensive and the result can be accurately read by any laboratory technician. Also, many samples can be tested at the same time. Its adoption will assist in monitoring patients who are on antiretroviral treatments, especially in developing countries where other methods of evaluating plasma loads of the virus are beyond income of average patients [2]. Such cheap and rapid method of assessing plasma HIV loads will also enhance testing of new ARTs, both in vitro and in vivo.

\section{REFERENCES}

[1] World health Organization (2007) Laboratory guidelines for enumerating CD4 T lymphocytes in the contest of HIV/AIDS. World Health Organization Regional Office for South-East Asia, New Delhi.

[2] Arya, S.C., Pathak, V.P., Ashrat, S.J. and Ashrat, S.K. (1989) Passive hemagglutination test for detection of antibodies of the Human Immunodeficiency Virus type 1 in developing countries. Journal of Clinical Microbiology, 27, 170174.

[3] www.hivinfosource.org.

[4] Vasudevachari, M.B., Ulfelman, K.W., Mast, T.C., Dewar, R.C., Natarajar, N., Lane, H.C. and Salzman, N.P. (1989) Passive hemagglutination test for detection of antibodies to the Human Immunedeficiency Virus type 1 and comparism of the test with ELISA and Western blot (Immuno- 
blot) analysis. Journal of Clinical Microbiology, 27, 179181.

[5] Ezeibe, M.C.O, Okoye, J.O.A., Ogunniran, T..M, Okoroafor, O.N., Ezeala, I.E., Ngene, A.A. (2012) Modification of the passive heamagglutination test for detection of Infectious Bursa Disease Virus. Health, 4, 653-655. doi:10.4236/health.2012.49102

[6] Wosu, L.O. (1984) Standardization of red blood cells for haemagglutination test and removal of natural agglutinins.
Nigerian Veterinary Journal, 13, 39-42.

[7] World Health Organization (2004) Consultation on technical and operational recommendations for scale-up of laboratory services and monitoring HIV antiretroviral therapy in resource-limited settings. WHO Office, Geneva.

[8] Center for Disease Control (2010) Cdc.gov/mmwr/preview/mmwrhtm 